them, and that the people concerned will be unable to carry out the kind of research needed to keep them on their toes. Worse still, however, it has already become plain that the relationship between the polytechnics and the universities is a potential source of serious trouble. If Mrs Thatcher really wants to make a mark-and by all accounts, she is that sort of person - she would be well advised to find some way in which the two systems can be married.

Basic research will be less of a problem, which is not to say there is nothing to be done. The truth is, however, that Mrs Thatcher inherits the makings of an efficient machine for the administration of basic science. Research councils are efficient instruments for channelling money to university researchers. There is a case for hoping that the Science Research Council can be given more leverage, at the expense of the others (which have what is called in the United States a mission to perform) and at the expense of what the University Grants Committee at present disburses for research-roughly $\mathfrak{\$ 4 5}$ million each year, which is something that Mrs Thatcher should worry about at an early stage. If there is to be much change by the next election, she will have to set the ball rolling now. It is also important that a start should be made on what is bound to be a long and slow pro. cess of integrating the university systems of Western Europe, in research as well as teaching. It will be a great disappointment for everybody if, ten years from now, it is not possible for a would-be university student from, say, Manchester to sign up as if by right for a university course at Nancy or Munich, and if graduates from the University of Rome cannot with equal ease take PhD degrees at Birmingham.

But is not the problem of science and technology that of finding some method of living with innovation? This is what the new government is likely most insistently to be asked. The past year has been remarkable for the way in which people have been asking that the science which made it possible for the expectation of life at birth to be multiplied by two should now devise some means by which the population of the world would shrink. Similarly, the intellectual disciplines which have provided methods of surface transport are now being asked to turn their attention to air pollution. And, of course, it is entirely proper that the potential beneficiaries of technology should ask for the best of both worlds-innovation but no evil consequences. So much must be accepted. Unhappily, the present tendency is for governments to align themselves with the fainthearts (many of them technical people) in some fake protest against the supposedly uncontrollable rush towards disaster which technology dictates. For politicians, the temptations of such an attitude are almost irresistible. Nevertheless, it would be a mark of courage if the new government could dig in its heels on this important matter. There is no reason why it should not combine a vigorous defence of the quality of British life with an old-fashioned belief that technical advance is a virtue.

\section{Dr Sydney Chapman}

THE death last week of Professor Sydney Chapman will cast a shadow on geophysics. He was a quite extraordinary person, in the best traditions of Mancunian independence. He was born before the discovery of X-rays, but he was one of those who in his sixtiesas chairman of the committee which ran the International Geophysical Year--entered into the planning of the first earth satellites with all the enthusiasm of a schoolboy. This cheerful exploitation of the twentieth century was one of his most endearing attributes. In time, no doubt, the legend will be that he cycled everywhere-even, it is said, on the freeways at Los Angeles -but he also regularly commuted between his offices at Boulder, Colorado, and College, Alaska, and managed also to turn up in London and Sydney with great if unpredictable regularity.

Travelling seems to have been a by-product of his enthusiasm. From the first outlines of the theory of how electrified particles might be trapped in the magnetic field of the Earth-which antedated the discovery of such particles by more than two decades Chapman bubbled over with ideas. As a result, he - to his more recent analysis of the solar wind. became an inspiration. People enjoyed working with him. By now, there is a multitude of them.

\section{Years Ago}

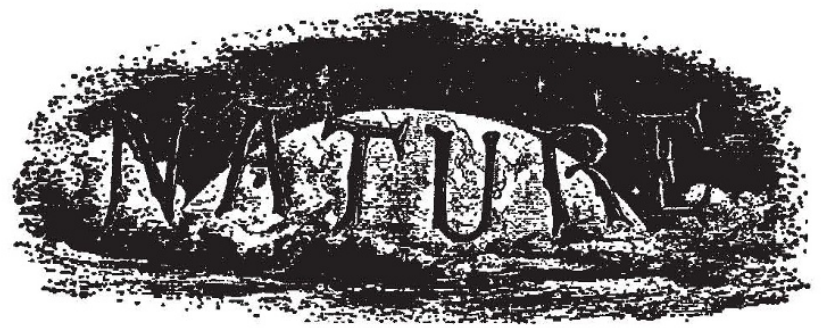

Dr. Heisch communicated a paper "On organic matter in water." The author was some time ago called on to assist a large manufacturer of lemonade, who suddenly found it impossible to make lemonade that would keep. After a day or two it becane turbid, and its odour anything but agreeable. On investigating the liquid under the microscope it was found full of small spherical cells with, in most cases, a very bright nucleus. After examining all the materials employed, the fault was cletected to be with the water. On putting a few grains of pure crystalline sugar into some of the water, it became turbid in a few hours, and contained the cells above mentioned. On inquiry it turned out that the well from which the water used in the preparation of the lemonate was obtained, had been slightly con. taminated with sewaye. This led the experimenter to mix a minute quantity of sewase with a sugar solution; the cells very soon made theirappearance. Filtration through the funest Swedish paper does not remove the germs. Boiling for half an hour in no way destroys their vitality. Filtration through a good bed of animal charcoal seems to be the only effectual mode of removing them, but it is necessary to air the charcoal from time to time, else it loses its purifying property.

From a report of a meeting of the Chemical Society (Nature, 2, 179, June 30, 1870). 